УДК 559+569(477.75)

DOI 10.18413/2658-3453-2020-2-4-298-309

\title{
К ФАУНЕ РУКОКРЫЛЫХ ГОРОДСКОГО ОКРУГА ФЕОДОСИЯ
}

\section{ON THE BAT FAUNA OF THE URBAN DISTRICT OF FEODOSIYA}

\author{
А.Н. Иваницкий \\ A.N. Ivanitsky \\ Карадагская научная станция - природный заповедник РАН - филиал ФИЦ ИнБЮМ, \\ Россия, 298188, Республика Крым, г. Феодосия, пос. Курортное, ул. Науки, 24 \\ Karadag Scientific Station - Nature Reserve of the Russian Academy of Sciences - \\ branch of Institute of Biology of the Southern Seas, \\ 24 Nauki St, Kurortnoe, Feodosiya, Republic of Crimea, 298188, Russia \\ E-mail: nathusii@mail.ru
}

\begin{abstract}
Аннотация
Фауна рукокрылых городского округа Феодосия включает 19 видов из 3-х семейств, включая 2 вида, которые в регионе не регистрировались более 70 лет. Нами впервые здесь зарегистрированы 5 видов: Myotis davidii, M. nattereri, Nyctalus leisleri, Pipistrellus pygmaeus и Plecotus auritus. В статье приводится перечисление всех известных в Большой Феодосии находок для каждого из видов, а для 17 из них добавлены также оригинальные находки. Наибольшим видовым разнообразием и наивысшим числом находок здесь отличается государственный природный заповедник «Карадагский» и его окрестности. Обсуждается также вероятность обнаружения ряда видов, отмеченных на сопредельных территориях.

Abstract

The bat fauna of the urban district of Feodosiya (or Great Feodosiya) composed 19 species of 3 families, including two species that have not been recorded in the region for more than 70 years. There is 5 species that we registered here for the first time: Myotis davidii, M. nattereri, Nyctalus leisleri, Pipistrellus pygmaeus and Plecotus auritus. The article contains a list of all known records in Great Feodosiya for each of the species, and for 17 of them original records are also added. There is the Karadag State Nature Reserve and its surroundings are distinguished by the greatest species diversity and the highest number of bat records. We also discuss the possibility of finding here some species of which are registered in the neighboring territories.
\end{abstract}

Ключевые слова: рукокрылые, Феодосия, Карадаг, распространение, находки.

Keywords: bats, Feodosiya, Karadag, distribution, records.

\section{Введение}

Городской округ Феодосия (г/о Феодосия, или Большая Феодосия) муниципальное образование на юго-востоке Крыма. История изучения фауны рукокрылых Большой Феодосии длится уже больше века, с 1913 г., и в основном связана с горным массивом Карадаг, где в 1914 г. Т.И. Вяземским была основана научная станция. Создание научной станции, а также в 1979 г. - Карадагского государственного природного заповедника определило регулярность зоологических исследований в описываемом регионе, в результате чего Карадаг сегодня выделяется на Крымском полуострове как одна из наиболее изученных в хироптерологическом отношении территорий. Кроме того, выявилась неравномерность изученности рукокрылых различных экологических групп. Благодаря мониторингу известных колоний в естественных убежищах на Карадаге наиболее изучены троглофилы - малый и большой подковоносы, длиннокрыл, остроухая и трёхцветная ночницы, а немногие дендрофильные и синантропные виды до наших исследований были известны в основном по единичным случайным находкам. Среди первых исследователей фауны рукокрылых Большой 
Феодосии были известные зоологи, в дальнейшем профессора, С.И. Огнёв, К.К. Флёров, Н.А. Бобринский [Огнев, 1928; Слудский, 2004-2005], их находки относились главным образом к Карадагу и его окрестностям. Из других исследователей рукокрылых региона первой половины XX в. наиболее интересны находки В.Н. Вучетича, Б.К. Штегмана, Б.М. Попова, С.А. Корнеева [Дулицкий, Коваленко, 2003]. В следующий период изучением фауны летучих мышей, наряду со своим основным объектом исследований, попутно занимались научные сотрудники Карадагской научной станции. В 1980-е гг. хироптерофауну Карадага изучал М.М. Бескаравайный [Бескаравайный, 1985, 1988, 1990; Бескаравайный, Шевченко, 1989], а в 2000-х и первой половине 2010-х гг. О.В. Кукушкин [Кукушкин, 2004, 2010; Кукушкин и др., 2007; Кукушкин, Покиньчереда, 2008, 2013], в том числе при участии украинских коллег. С 2017 г. в регионе начались наши специальные исследования фауны рукокрылых. Актуальность работы не вызывает сомнений, так как фауна рукокрылых г/о Феодосия, не смотря на более чем вековую историю исследований, остаётся недостаточно изученной, исследования находятся на стадии инвентаризации. Без достоверных знаний о хироптерофауне региона затруднительно судить о роли летучих мышей в местных экосистемах и невозможно наметить здесь пути сохранения этих редких и уязвимых животных. Это обстоятельство и определило цель данной статьи - собрать в одной работе как известные ранее сведения о находках рукокрылых в Большой Феодосии, так и данные собственных исследований.

\section{Характеристика района исследования}

Городской округ Феодосия - административно-территориальная единица Республики Крым, образованная городом республиканского значения Феодосия с подчинённой ему территорией, на которой располагаются 5 посёлков городского типа и 12 сёл. Площадь городского округа - 350.4 км$^{2}$, наибольшая длина - 46.5 км, при ширине - 4.5-17 км. Расположен г/о Феодосия на побережье Чёрного моря, в юговосточной части Крымского полуострова. В географическом отношении регион представляет интерес как переходная территория от Горного Крыма (хр. Тепе-Оба является восточным окончанием Главного хребта Крымских гор) к степям Равнинного Крыма. На крайнем юго-западе городского округа преобладает лесная растительность: на холмах вокруг Краснокаменки и Щебетовки дубовые и смешанные леса, на Карадаге - в основном редколесья дубовые, фисташковые и др. В центральной части - разнотравноковыльные степи, а также земли сельскохозяйственного использования, в основном виноградники. На северо-востоке Большой Феодосии - галофитные луга на засоленных почвах, в комплексе с бедными разнотравными степями.

\section{Материалы и методы исследования}

Исследования проводились в г/о Феодосия с апреля 2017 г. по сентябрь 2020 г. За этот период сделаны 46 находок 15-ти видов 2-х семейств, из них 5 видов здесь найдены впервые.

В дневное время осуществляли поиски рукокрылых в потенциальных для них убежищах - в скальных и приморских гротах Карадагского заповедника и других возможных местах днёвок рукокрылых. Ночью рукокрылых отлавливали двумя паутинными сетями $(5 \times 10$ м). Ловчие сети растягивали между стойками, в качестве которых использовали парные телескопические удилища высотой 6.5 и 12 м, установленные на растяжках. Отловленные летучие мыши, после проведения стандартных прижизненных исследований и фотографирования, выпускались в местах отлова, в отдельных случаях перед выпуском рукокрылых окольцовывали. С целью идентификации видов рукокрылых по акустическим сигналам применяли ультразвуковой детектор D-240x (Pettersson Elektronik AB, Швеция).

Исследования рукокрылых в г/о Феодосия проводились в разные годы в следующих пунктах (пункты оригинальных находок приводятся с координатами) (см. рисунок): 
1) «Ближние Камыши» (северно-восточная окраина г. Феодосия) (4505'05" N $\left.35^{\circ} 24^{\prime} 00^{\prime \prime} \mathrm{E}\right)$;

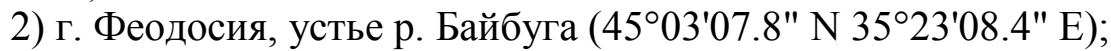

3) хр. Тепе-Оба $\left(45^{\circ} 00^{\prime} 35^{\prime \prime} \mathrm{N} 35^{\circ} 21^{\prime} 25^{\prime \prime} \mathrm{E}\right)$;

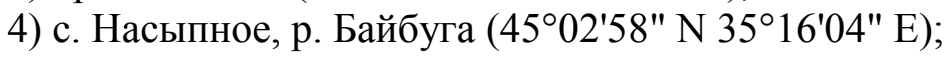

5) пгт Орджоникидзе;

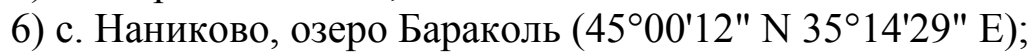

7) пгт Коктебель;

8) Карадаг, хр. Сюрю-Кая;

9) Карадаг, здание станции экологического мониторинга;

10) Карадаг, грот в бухте Барахта, грот Ревущий;

11) Карадаг, приморские гроты Берегового хребта (Мышиная Щель, Голубиный, Левинсона-Лессинга), Львиная бухта;

12) Карадаг, Кузмичев Камень (445' $41.8^{\prime \prime}$ N $35^{\circ} 12^{\prime} 45.4^{\prime \prime}$ E);

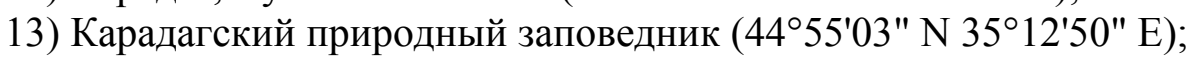

14) Карадагская научная станция (445' $\left.49.5^{\prime \prime} \mathrm{N} 35^{\circ} 12^{\prime} 03.4^{\prime \prime} \mathrm{E}\right)$;

15) пгт Курортное, подвал заброшенного здания (4454'31.7" N 30¹0'56.9" Е);

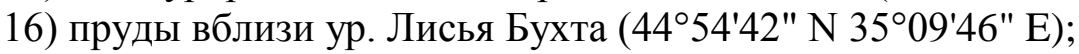

17) ур. Лисья Бухта;

18) дорога Щебетовка-Курортное, р. Отузка;

19) пгт Щебетовка (Отузы);

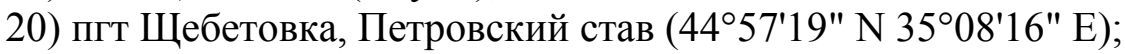

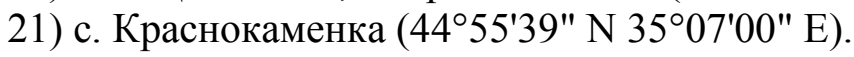

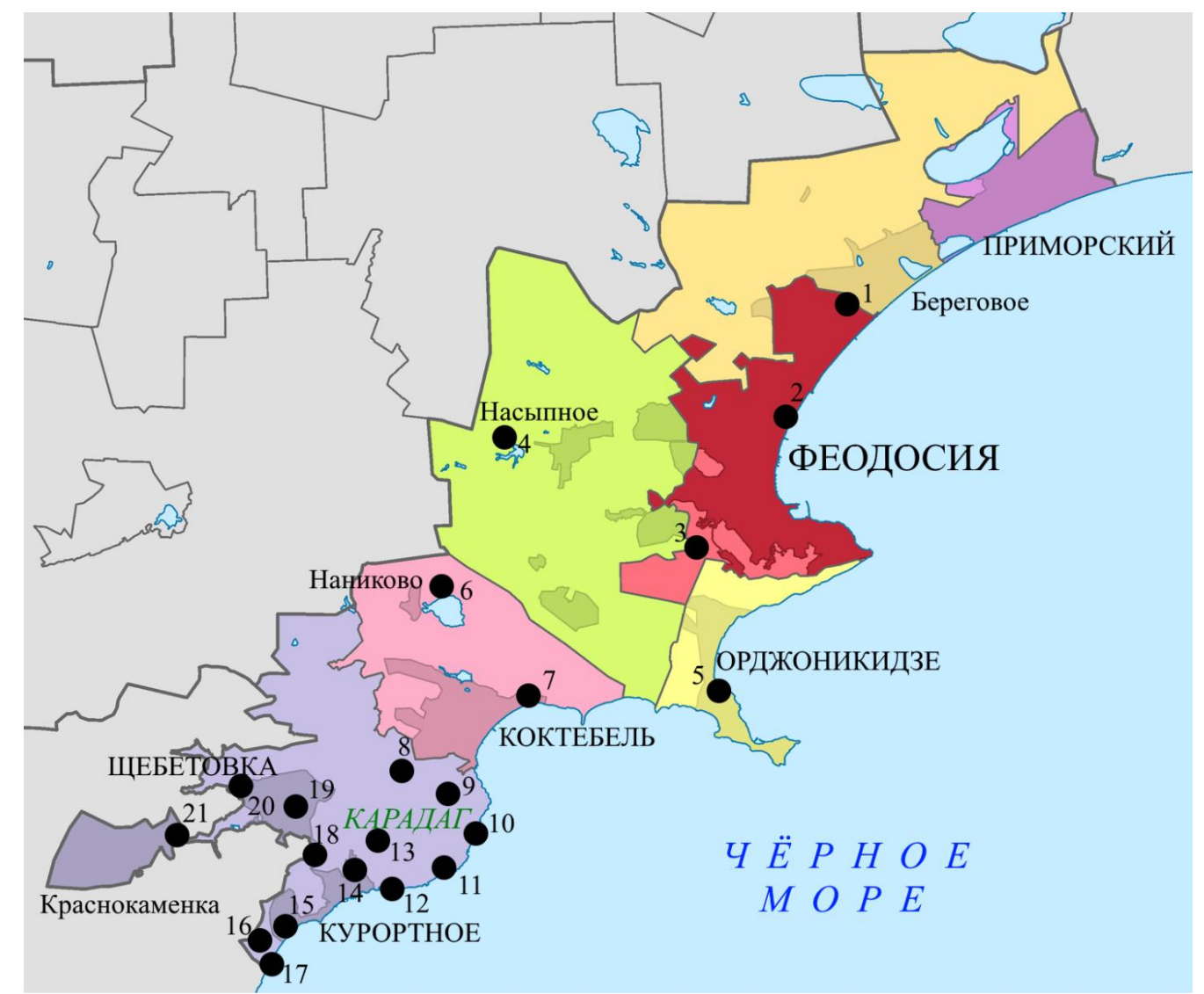

Рис. 1. Примерное расположение пунктов находок рукокрылых в городском округе Феодосия (пояснения см. в тексте)

Fig. 1. The approximate location of bat records in the urban district of Great Feodosiya (see text for explanation) 


\section{Результаты и их обсуждение}

Фауна рукокрылых Большой Феодосии включает 19 видов из 3 семейств. Ниже приводятся обобщённые сведения по всем видам рукокрылых, зарегистрированным в г/о Феодосия, включая данные результатов собственных исследований и почерпнутые из литературных источников. Информация о коллекционных экземплярах в различных музеях нами приводится по сводке А.И. Дулицкого и И.С. Коваленко [2003]. Также, часть приведённых ниже оригинальных данных нами была опубликована ранее [Иваницкий и др., 2018, 2019а; Смирнов и др., 2017].

Принятые в тексте сокращения: ЗИН - Зоологический институт РАН (г. СанктПетербург), ЗММУ - Зоологический музей Московского государственного университета им. М.В. Ломоносова (г. Москва), КГУ - Зоологический музей Киевского государственного университета (г. Киев), НМАНУ - Национальный научноприродоведческий музей НАН Украины (г. Киев), ЛПМ - Львовский природоведческий музей (г. Львов), КЗОХ - Крымское государственное охотничье заповедное хозяйство (г. Алушта); в. к. - выводковая колония, ad - взрослая особь, sad - молодая особь, juv детёныш, $\widehat{\sigma}$ - самец,, - самка, ос. - особь, без уточнения пола и возраста, г. - город, пгт - посёлок городского типа, с. - село, хр. - хребет, ур. - урочище.

Сем. RHINOLOPHIDAE Gray, 1825

1. Малый подковонос - Rhinolophus hipposideros (Borkhausen, 1797).

Впервые в Большой Феодосии найден в 1925 г. К.К. Флёровым на Карадаге [колл. ЗИН]. Встречается в гротах, а также различных строениях (подвалы, чердаки и т.п.) единично и группками до трёх десятков особей.

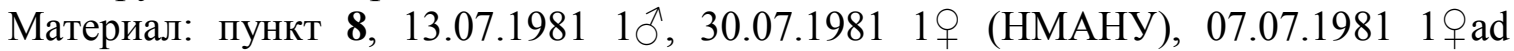
(КЗОХ), 24.07.1987 единично [Бескаравайный, 1988], 26.07.-06.08.2002 7움ㅇ и 7juv [Лопатюк, 2008]; 9, 1981-1983 гг. единично [Бескаравайный, 1988], 27.05.2003 1 ос. [Кукушкин, 2004], 26.07.-06.08.2002 32 ос., в т. ч. 1juv [Лопатюк, 2008]; 11, 03.07.1960 1ð (ЗИН), 28.06.2006 1 ос. [Кукушкин, Покиньчереда, 2008]; 12, 24.07.1987 1 с с juv [Бескаравайный, 1988, 1990], 26.07.-06.08.2002 3ad [Лопатюк, 2008], 25.07.2017 - 1 $^{\mathrm{ad}}$

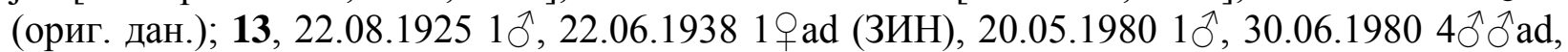
$19 \mathrm{ad}, 3$ 9 juv и 2 ос. (НМАНУ), 26.07.-06.08.2002 4ㅇ 9 ad с 4јuv и 1 ос. [Лопатюк, 2008]; 30.05.2008 2 ос., 10.07.2008 1 ос., 11.07.2008 3 ос., 28.07.2008 7 ос.: 3 q $9 \mathrm{ad}, 3 \mathrm{juv}, 1 \mathrm{sad}$ и 1 ос., 30.07.2008 2 ос. [Кукушкин, 2010], 30.07.2013 - 2 ос. [Кукушкин, Покиньчереда, 2013]; 15, 21.04.2017 29 $9 \mathrm{ad}$ беременные, 24.07.2017 1§̂sad и 1 ос., 19.09.2020 2 особь (ориг. дан.).

2. Большой подковонос - Rhinolophus ferrumequinum (Schreber, 1774).

В описываемом районе известен с 1935 г. (Штегман Б.К.). Найден только в крайней южной периферии городского округа, в Природном заповеднике «Карадагский» и его окрестностях. Убежищами здесь служат в основном гроты, в т. ч. приморские, реже постройки. Встречается как одиночными особями, так и колониями до 200 особей.

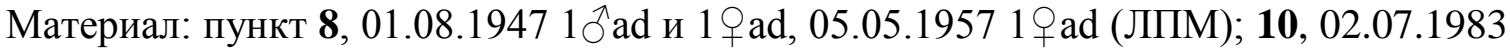
30 우 [Бескаравайный, 1988], 28.06.2008 150 ос. [Кукушкин, 2010], 16.08. и 19.08.2013 5070 ос. [Кукушкин, Покиньчереда, 2013]; 10-11, 1981-1983 гг. единично [Бескаравайный, 1988]; 11, 24.07.1981 1q, 13.08.1987 $1 q$ sad (НМАНУ), 08.07.1986 в. к. $q 9$ с juv [Бескаравайный, Шевченко, 1989], 13.08.1987 в. к. 250 ос. [Бескаравайный, 1990], июль 198150 ос., 198250 ос., июль 1983150 ос. [Бескаравайный, 1988], 13.08.1988 1 \% [Zagorodniuk, 1999], август 2001200 oc. [Bat census ..., 2007], 30.07.2019 10 oc., 21.07.2020 единично (ориг. дан.); 12, июль 1960 2јuv (ЗИН), 24.06.2004 200 ос., 06.08.2004 200 ос., 09.07.2005 в. к. 200 ос., 16.07.2005 200 ос., 19.07.2005 150 ос., 24.07.2005 150 ос., 27.07.2005 150 ос., 10.08.2005 150 ос., 27.08.2005 50-70 ос. [Кукушкин и др., 2007], 07.07.2006 150 ос., 23.07.2006 200 ос., 23.08.2006 100 ос. [Кукушкин, Покиньчереда, 2008]; «год не указан» 150 ос. [Кукушкин, Покиньчереда, 2008], 15.05.2008 4 ос., 10.06.2008 
25 ос. [Кукушкин, 2010], 22.05.2013 - 5-7 ос. [Кукушкин, Покиньчереда, 2013]; 13,

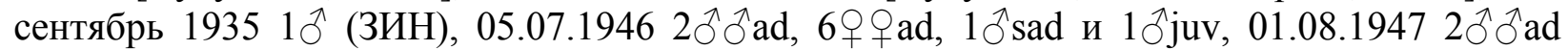
(КГУ), 22.06.1980 1ठ (НМАНУ), «Год не указан» 3ठ [Бескаравайный, 1988], 30.08.2006 1 ос. [Кукушкин, Покиньчереда, 2008], 19.08.2008 1 ос. [Кукушкин, 2010], 06.06.2018 1 ос. (ориг. дан.); 15, 19.09.2020 - 1 особь (ориг. дан.); 16, 07.06.2019 - 1 ос. (ориг. дан.).

Сем. VESPERTILIONIDAE Gray, 1821

3-4. Степная ночница - Myotis davidii Peters, 1869 и усатая ночница - Myotis mystacinus (Kuhl, 1817) - мелкие ночницы группы «mystacinus».

Находки до 2017 г. сделаны до ревизии видов группы «mystacinus», и все они были отнесены к M. mystacinus s. lato, без различия не только на M. davidii и M. mystacinus s. str., но и включающую короткопалую ночницу (M. alcathoe Helversen et Heller, 2001) и ночницу Брандта (M. brandtii (Eversmann,1845)). Два последних вида достоверно известны из сопредельных территорий Крыма и Кавказа, а их ближайшие находки отстоят на расстояние 70-150 км от границ г/о Феодосия [Benda et al., 2016]. К какому из этих четырёх видов в действительности принадлежали старые экземпляры в настоящее время определить затруднительно. Все оригинальные находки относятся к M. davidii.

Материал: пункт 2, 18.04. и 24.04.2017 1 ос. (ориг. дан.); 4, $02.06 .201819 \mathrm{ad}$ беременная (ориг. дан.); 12, 22.08.-08.09.1982 3ภิ ภิ [Бескаравайный, Шевченко, 1989]; 13, 01.07.1960 5우 (ЗИН), сентябрь 1972 1ㅇ, 25.08.1982 1ઈ (НМАНУ); 21, 09.06.2018 2 우 беременные, 24.06.2019 1 т лактирующая (ориг. дан.).

5. Ночница Наттерера - Myotis nattereri (Kuhl, 1817).

Ночница Наттерера в Крыму, как и в других регионах южной части его ареала, редкий, малоизученный вид.

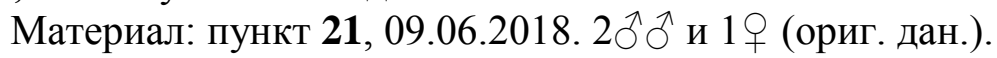

6. Трёхцветная ночница - Myotis emarginatus (Geoffroy St.-Hilaire, 1806).

В Большой Феодосии впервые была обнаружена С.А. Корнеевым более чем 70 лет назад. До настоящего времени эта ночница зарегистрирована только на Карадаге, через который проходит северная граница распространения вида.

Материал: пункт 8, 31.07.1947 1qjuv, 01.08.1947 1ठ (КГУ); 11, 26.08.2006 200 ос. [Кукушкин, Покиньчереда, 2008]; 12, 24.06.2004 200 ос., 06.08.2004 200 ос., 09.07.2005 в. к. 200 ос., 16.07.2005 200 ос., 19.07.2005 100 ос., 24.07.2005 50 ос., 27.07.2005 50 ос. [Кукушкин и др., 2007], 13.05.2006 70 ос., 07.07.2006 200 ос. [Кукушкин, Покиньчереда, 2008], 15.05.2008 350 ос., 10.06.2008 50 ос. [Кукушкин, 2010]; 13, 06.06.1960 - 2 q $\mathrm{ad}$

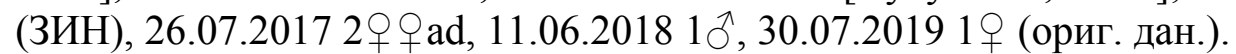

7. Остроухая ночница - Myotis blythii (Tomes, 1857).

Впервые в г/о Феодосия впервые найден в июле 1925 г. на Карадаге К.К. Флёровым. Все известные находки вида в регионе, включая находки крупных колоний, относятся к Карадагскому заповеднику и его окрестностям.

Материал: пункт 10, 13.08.1987 [Бескаравайный, 1990], 26.08.2006 неизв. [Кукушкин, Покиньчереда, 2008], 06.06.2018 несколько особей (ориг. дан.); 10-11, 12.08.2005 неизвестно [Кукушкин и др., 2007], 30.07 .2019 до 500 ос., 21.07.2020 несколько сотен (ориг.

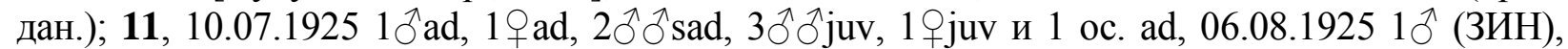

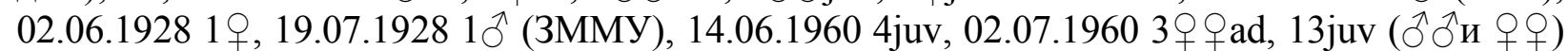
(ЗИН), лето 1974 150 9 ad беременные, 198250 ос. [Бескаравайный, 1988], 1981-1983 150200 ос., 13.08.1987 единично [Бескаравайный, 1988, 1990], июнь 2004300 우 [Bat census ..., 2007], 26.08.2006 20 ос. [Кукушкин, Покиньчереда, 2008], 06.06.2018 350 ос. (ориг. дан.); 12,

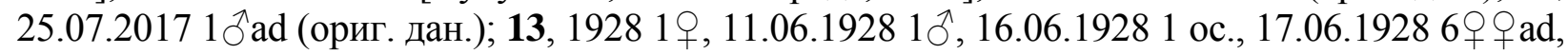
17.12.1928 1 ,, $19.07 .19293 q \circ$ (ЗММУ), 27.06.1946 в. к., в т. ч. 35 ос., 04.07.1946 в. к., в т. ч.

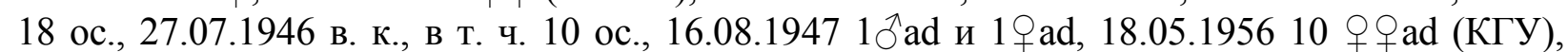

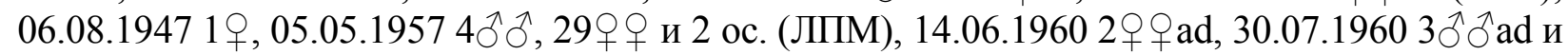




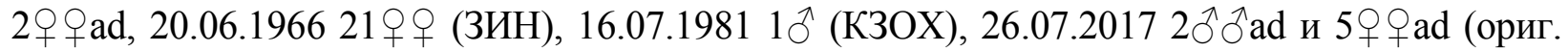
дан.); 13 и 19, 02.08.1928 - 2ઈิð и 2 우 (ЗММУ); 14, 05.07.2019 $4 \mathrm{sad}$ (ориг. дан.); 16, 07.06.2019 1 q ad лактирующая (ориг. дан.).

8. Рыжая вечерница - Nyctalus noctula (Schreber, 1774).

В Большой Феодосии зарегистрирован как в тёплый период, так и на зимовке, а находка выводковой колонии свидетельствует о том, что в Крыму имеется и осёдлая популяция этого вида. Все известные находки рыжей вечерницы относятся к последним 15 годам.

Материал: пункт 1, май-сентябрь 2012 в. к., в т. ч. 11ad c juv (Розенберг О.Г., личн.

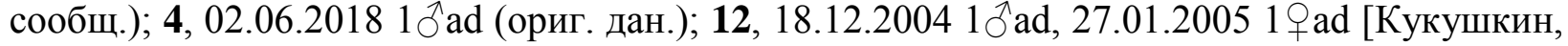
2006]; 14, 13.04.2018 1 qad (ориг. дан.).

9. Малая вечерница - Nyctalus leisleri (Kuhl, 1817).

Материал: пункт 3, 03.06.2018 1 qad беременная (ориг. дан.); 4, 02.06.2018 1 ad беременная (ориг. дан.); 13, 30.07.2019 1q (ориг. дан.); 21, 24.06.20191q лактирующая (ориг. дан.).

10. Нетопырь-карлик - Pipistrellus pipistrellus (Schreber, 1774).

Нетопырь-карлик - первый вид рукокрылых, зарегистрированный в Большой Феодосии, впервые найден С.И. Огнёвым в мае 1913 г. на Карадаге. В городском округе распространён широко, вид с высокой встречаемостью. Находки до 2017 г. относятся к P. pipistrellus s. lato, без различения на ныне выделяемые виды P. pipistrellus s. str. и P.pygmaeus.

Материал: пункт 4, 02.06.2018 19 беременная (ориг. дан.); 6, 07.06.2018 1 q беременная (ориг. дан.); 9, 28.03.2003 1§ [Кукушкин, 2004]; 13, 18.05.1913 1§, сентябрь

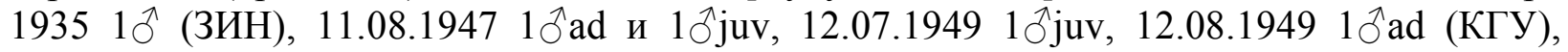
21.07.1981 1 $\bigcirc^{\lambda}$ ad (K3OX), 25.06.2004 1ठ, 26.06.2004 2 oc. [Bat census ..., 2007]; 14, 1981

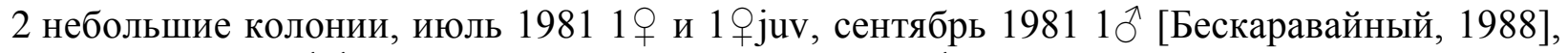

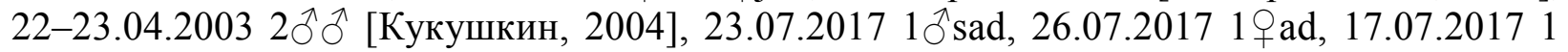
ос., 19.07.2017 2 бิ 28.03.2003 7-8 ос. [Кукушкин, 2004]; 16, 07.06.2019 3 q 9 лактирующие (ориг. дан.); 17, 24.06.2004 - 1우 [Bat census ..., 2007]; 19, 05.07.1957 1우 (ЛПМ); 21, 09.06.2018 1 웅 беременная (ориг. дан.).

11. Тонкоголосый нетопырь - Pipistrellus pygmaeus (Leach, 1825).

Тонкоголосый нетопырь ранее рассматривался в составе предыдущего вида.

Материал: пункт 2, 08.04. и 24.04.2017 10 ос. (ориг. дан.); 21, 24.06.2019 1 §ad (ориг. дан.).

12. Лесной нетопырь - Pipistrellus nathusii (Keyserling et Blasius, 1839).

В Большой Феодосии известен по единственной находке К.К. Флёрова в 1925 г. на Карадаге в Тумановой балке, представляющей интерес и тем, что она подтверждает размножение этого перелётного вида в Крыму.

Материал: пункт 13, 11.08.1925 3 + 9 и 5juv (ЗИН).

13. Средиземноморский нетопырь - Pipistrellus kuhlii (Kuhl, 1817).

В настоящее время в г/о Феодосия этот синантропный вид распространён широко. Средиземноморский нетопырь в городском округе известен с начала 1980-х гг., при этом появление его в Феодосии, по-видимому, связано больше не с известной экспансией ареала у этого вида [Иваницкий, 2018], которая, должно быть, только увеличила его встречаемость в Большой Феодосии, а со слабой изученностью в регионе нетроглофильных видов. В пользу этого говорит тот факт, что в Горном Крыму, на Южном побережье Крыма средиземноморский нетопырь известен с конца XIX - начала XX вв. [Браунер, 1911], и старые находки отстоят от Феодосии на расстояние около 80 км. Другим подтверждением являются находки здесь примерно в это же время других видов 
рукокрылых (двуцветный кожан, европейская широкоушка), а в более поздние годы - и многих других видов, древнее обитание в регионе которых никто не ставит под сомнение.

Материал: пункт 3, 03.06.2018 10َ (ориг. дан.); 5, октябрь 1981 1ठ̄ad [Бескаравайный, 1985]; 7, «год и число особей не указано» [Вронский и др., 1997]; 14,

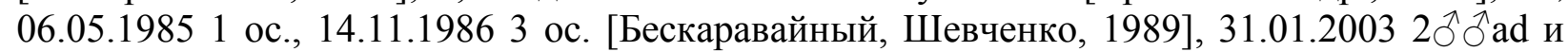
$19 \mathrm{ad}, 16.09 .20031 \delta$ [Кукушкин, 2004], 28.04.2004 1ð [Кукушкин, 2006], 10.04.2006 1ठ, 17.08.2006 1ठ [Кукушкин, Покиньчереда, 2008], 20.04.2017 1 ос., 10.09.2019 $1 ठ \mathrm{ad,}$

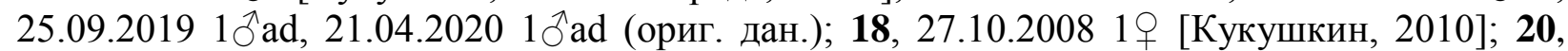

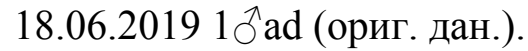

14. Кожановидный нетопырь - Hypsugo savii (Bonaparte, 1837).

В исследуемом регионе вид известен уже более 100 лет, со времён находки В.Н. Вучетичем в мае 1920 г. на Карадаге. Кожановидный нетопырь относится к редким, южным периферийным видам, к настоящему времени известны лишь три находки одиночных самцов.

Материал: пункт 14, 15.05.1920 1 ос. [Огнев, 1928], 15.08.1990 1ठ (НМАНУ), 06.08.2020 1ð^sad (ориг. дан.).

15. Двуцветный кожан - Vespertilio murinus Linnaeus, 1758.

В Большой Феодосии известен по единственной находке М.М. Бескаравайного.

Материал: пункт 13, 04.07.1988 1ठ (НМАНУ).

16. Поздний кожан - Eptesicus serotinus (Schreber, 1774).

Немногочисленные находки этого кожана известны в г/о Феодосия с 1918 г.

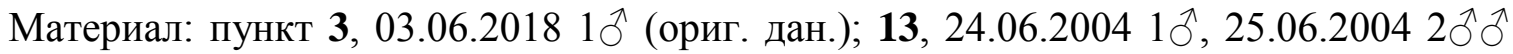
[Bat census ..., 2007], 11.06.2018 1ठ̄sad (ориг. дан.); 18, 08.04.1918 19 (ЗММУ).

17. Европейская широкоушка - Barbastella barbastellus (Schreber, 1774)

В г/о Феодосии известны три находки одиночных особей этого вида с интервалом в 15-20 лет, все они относятся к Карадагскому заповеднику.

Материал: пункт 13, 30.06.1981 1ठ [Бескаравайный, Шевченко, 1989], 11.06.2018 1 ad беременная (ориг. дан.); 14, 08.10.2003 1 [Кукушкин, 2004].

18. Бурый ушан - Plecotus auritus (Linnaeus, 1758).

Отмеченный на Карадаге ранее ушан приводился без уточнения видовой принадлежности [Кукушкин, 2004], вследствие чего эта находка могла относится как к бурому (Pl. auritus), так и к серому ушану (Plecotus austriacus (Fischer, 1829)), ранее включавшемуся в состав Pl. auritus. Серый ушан был обнаружен нами в 45 км от находки на Карадагской станции экологического мониторинга, в западной части Керченского полуострова [Иваницкий и др., 2019б], но на описываемой здесь территории вид пока достоверно не отмечен.

Материал: пункт 9, 27.05.2003 1 ос., как Plecotus sp. [Кукушкин, 2004]; 21, 09.06.2018 1ð и 5 ㅇ $q$ беременные (ориг. дан.).

Сем. Miniopteridae Bonaparte, 1837

19. Обыкновенный длиннокрыл - Miniopterus schreibersii (Kuhl, 1817).

В г/о Феодосия этот высококолониальный и троглофильный вид известен по находкам первой половины XX в. только из Карадагского заповедника и прилежащих территорий. В 1920-е гг. в приморском гроте Мышиная Щель обитала многовидовая колония, численностью свыше 40 тысяч особей, включавшая, кроме длиннокрылов, ночниц и подковоносов [Слудский, 2004-2005].

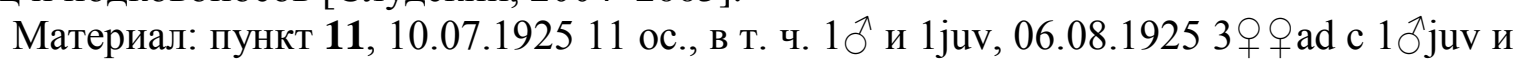

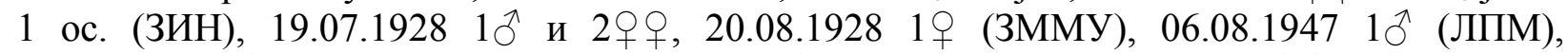

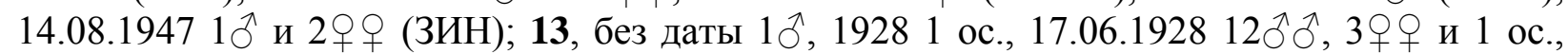

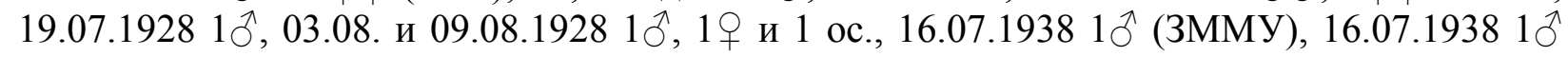




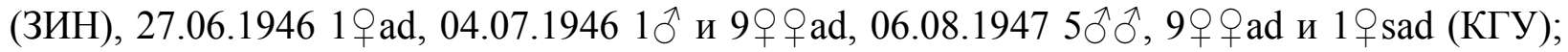
19, 03.07.1928 1ठึ (3MMY).

До настоящего времени в Феодосии отсутствуют достоверные находки выше упомянутых ночницы Брандта (Myotis brandtii) и серого ушана (Plecotus austriacus), отмеченых в соседних административных районах Крыма. Не зарегистрирована и известная для Крымского полуострова гигантская вечерница (Nyctalus lasiopterus (Schreber, 1780)) [Дулицкий, Коваленко, 2003], что не удивительно для этого редкого вида, учитывая, что другие, более многочисленные виды вечерниц, - рыжая и малая в Феодосии найдены лишь в последние годы. Нельзя исключить обнаружение здесь и двух других видов - прудовой ночницы (Myotis dasycneme (Boie, 1825)) и широкоухого складчатогуба (Tadarida teniotis (Rafinesque, 1814)), известных по единичным находкам в соседних районах Крыма, ближайшие из которых в 80 и 40 км от границ г/о Феодосия соответственно [Годлевская и др., 2013; Uhrin et al., 2009]. Но учитывая информацию об экологии и распространении рукокрылых в Причерноморье, более вероятными нам представляются находки водяной (Myotis daubentonii (Kuhl, 1817)) и длинноухой (Myotis bechsteinii (Kuhl, 1817)) ночниц, зарегистрированных в окрестностях г. Анапы Краснодарского края в 140-150 км к востоку от исследуемого района [Кожурина и др., 2002], при этом Феодосия, как крайняя восточная периферия Горного Крыма, ближайшая к Кавказу, для обнаружения этих видов наиболее перспективна. Для полноты картины о хироптерофауне региона следует упомянуть о сообщениях об обнаружении подковоносов группы «еuryale», когда на основании ошибочного определения молодой самки большого подковоноса, найденной 13.08.1988 на Карадаге в гроте Мышиная Щель, было сделано заключение об обитании в регионе сразу двух видов - южного (Rhinolophus euryale Blasius, 1853) и очкового (Rhinolophus mehelyi Matschie, 1901) подковоносов [Дулицький, Михайлова, 2001; Zagorodniuk, 1999]. Ранеe нами было уже выражено сомнение по поводу возможности находок этих двух видов подковоносов в Крыму [Turbanov, Ivanitsky, 2018].

Исходя их вышеизложенного, становится очевидной актуальность дальнейших исследований фауны рукокрылых Большой Феодосии. Другой причиной, актуализирующей здесь хироптерологические исследования, является потребность в достоверных данных о редких и уязвимых животных, к которым, несомненно, относится большинство видов летучих мышей региона. Такие данные могли бы быть использованы при планировании и организации природоохранных мероприятий. Тем более что г/о Феодосия - регион Южного берега Крыма, находящийся под мощнейшим прессом рекреационной деятельности, где кроме всего прочего реализуются крупные инфраструктурные проекты.

\section{Заключение}

В настоящее время в г/о Феодосия установлено обитание 19 видов из 3-х семейств. Наши трехлетние исследования в данном регионе выявили 17 видов, из них 5 (M. davidii, M. nattereri, N. leisleri, P. pygmaeus и P. auritus) - в Большой Феодосии зарегистрированы впервые. Значительно расширена география находок рукокрылых в регионе. Распространение 10 видов (R.hipposideros, $R$. ferrumequinum, M. nattereri, M. emarginatus, M. blythii, P. nathusii, H. savii, V. murinus, B. barbastellus и M. schreibersii) связано с горным массивом Карадаг и его окрестностями, остальные виды распространены в регионе широко. Существенно увеличены представления характере пребывания многих видов. Для 14 видов установлено размножение в регионе, причём для 8 видов (M. davidii, M. nattereri, N. noctula, N. leisleri, H. savii, E. serotinus, B. barbastellus и P. auritus) - нами впервые. 


\section{Благодарности}

Автор выражает благодарность д.б.н. Д.Г. Смирнову и к.б.н. Н.М. Салдаевой (ПГУ, г. Пенза), к.б.н. Д.А. Васенькову и к.б.н. Н.В. Сидорчук (ИПЭЭ РАН, г. Москва), чл.-корр. РАН Н.С. Чернещову (ЗИН РАН, г. Санкт-Петербург), О.Г. Розенбергу (ЦДО «Интеллект», г. Феодосия), Г.А. Прокопову (КФУ, г. Симферополь), а также к.б.н. М.М. Бескаравайному, О.В. Кукушкину и К.И. Шоренко (КНС-ПЗ РАН, пгт Курортное) за совместные полевые исследования и предоставленные данные, в том числе неопубликованные.

Работа выполнена в рамках темы госзадания № АAАA-A19-119012490044-3 (Изучение особенностей структуры и динамики сухопутных экосистем в различных климатических зонах).

\section{Список литературы}

1. Бескаравайный М.M. 1985. О новой находке средиземноморского нетопыря в Крыму. Вестник зоологии, 4: 82-83.

2. Бескаравайный М.М. 1988. Современное состояние фауны рукокрылых Карадага (Крым). В кн.: Рукокрылые (морфология, экология, эхолокация, паразиты, охрана). Сборник научных трудов. Киев, Наукова думка: 113-116.

3. Бескаравайный М. М., Шевченко Л. С. 1989. Млекопитающие. В кн.: Природа Карадага. Киев, Наукова думка: 221-228.

4. Бескаравайный М.M. 1990. Млекопитающие. В кн.: Карадагский государственный заповедник АН УССР. Летопись природы. 1987. Том IV. Книга 2. Симферополь, Редотдел Крымского облполиграфиздата: 74-75.

5. Браунер А.А. 1911. Летучие мыши Крыма. Записки Крымского общества естествоиспытателей и любителей природы, 1: 1-13.

6. Вронский, А.А., Кривобоков Е.М., Костенко Н.С., Баранов И.А., Бескаравайный М.М., Будашкин Ю.И., Владимиров Е.И., Клюкин А.А., Пьяных С.В., Семеньков П.Г., Шатко В.Г., Щепинский А.А. 1997. Курорт Коктебель. Киев, Наукова думка, 134 с.

7. Годлевская Е.В., Гхазали М.А., Тищенко В.Н. 2013. Первая находка Myotis dasycneme (Chiroptera) в Крыму. Вестник зоологии, 47(1): 38.

8. Дулицкий А.И., Коваленко И.С. 2003. Материалы по рукокрылым Крыма в зоологических собраниях Украины и России. $B$ кн.: Вопросы развития Крыма: Проблемы инвентаризации крымской биоты. Вып. 15. Симферополь, «Таврия Плюс»: 197-210.

9. Дулицький А., Михайлова О. 2001. До характеру перебування кажанів на территорії Криму. В кн.: Міграційний статус кажанів Україні. Київ, УТТ: 106-109.

10. Иваницкий А.Н. 2018. Рукокрылые (Chiroptera) Абхазии и сопредельных территорий (фауна, экология, зоогеография, охрана). Симферополь, ИТ «АРИАЛ», 156 с.

11. Иваницкий А.Н., Васеньков Д.А., Сидорчук Н.В. 2019а. Новые фаунистические находки рукокрылых на востоке Крыма. Plecotus et al., 22: 69-79.

12. Иваницкий А.Н., Розенберг О.Г., Шоренко К.И. 2019б. Ак-Монайские каменоломни ключевое убежище рукокрылых Восточного Крыма. Экосистемы, 20 (50): 140-148.

13. Иваницкий А.Н., Сидорчук Н.В., Васеньков Д.А. 2018. Новые данные по рукокрылым восточной части Южного берега Крыма. Экосистемь, 16 (46): 117-122.

14. Кожурина Е.И., Борисенко А.В., Панютина А.А., Морозов П.Н. 2002. К изучению рукокрылых Абрау. В кн.: Биоразнообразие полуострова Абрау. М., МГУ: 106-112.

15. Кукушкин O.В. 2004. Отряд Рукокрылые (Chiroptera). В кн.: Карадагский природный заповедник НАН Украины. Летопись природы. Т. ХХ. 2003 год. Симферополь, СОНАТ: 239-240.

16. Кукушкин О.В. 2010. Наблюдения над редкими видами рукокрылых Карадага. $B$ кн.: Карадагский природный заповедник НАН Украины. Летопись природы. Т. XXV. 2008 год. Симферополь, Н. Оріанда: 277-280.

17. Кукушкин О.В., Покиньчереда В.Ф. 2008. Результаты учетов рукокрылых в Карадагском природном заповеднике. $B$ кн.: Карадагский природный заповедник НАН Украины. Летопись природы. Т. 23. 2006 год. Симферополь, Н. Оріанда: 305-309. 
18. Кукушкин О.В., Покиньчереда В.Ф. 2014. Рукокрылые. Наблюдения в Карадагском заповеднике в 2013 г. В кн.: Карадагский природный заповедник НАН Украины. Летопись природы. Т. ХXX. 2013 год. Карадаг: 140-141.

19. Кукушкин О.В., Покиньчереда В.Ф., Бескаравайный М.М., Красников А.Е. 2007. Наблюдения над совместной материнской колонией двух редких видов рукокрылых (Chiroptera) в Карадагском заповеднике в 2005 году. B кн.: Карадагский природный заповедник НАН Украины. Летопись природы. Т. ХХІІ. 2005 год. Симферополь, СОНАТ: 292-297.

20. Лопатюк А.Л. 2008. Находки малого подковоноса (Rhinolophus hipposideros Bechstein, $1800)$ в Карадагском заповеднике. $B$ кн.: Карадагский природный заповедник НАН Украины. Летопись природы. Т. ХХІІІ. 2006 год. Симферополь, Н. Оріанда: 303-305.

21. Огнев С.И. 1928. Звери Восточной Европы и Северной Азии. Т. 1. Насекомоядные и летучие мыши. М.-Л., Госиздат, 631 с.

22. Слудский Е.А. 2004-2005. Карадаг. Воспоминания (1917-1926 гг.). Симферополь, COHAT, $112 \mathrm{c}$.

23. Смирнов Д.Г. Курмаева Н.М., Иваницкий А.Н. 2017. К изучению рукокрылых (Chiroptera) на Востоке Крыма. Plecotus et al., 20: 17-29.

24. Bat census in Crimean caves. 2007. A final report on the BP Conservation project. L. Godlevska (project leader). Kyiv, $41 \mathrm{p}$.

25. Benda P., Gazaryan S., Vallo P. 2016. On the distribution and taxonomy of bats of the Myotis mystacinus mophogroup from the Caucasus region (Chiroptera: Vespertilinidae). Turkish Journal of Zoology, 40: 1-8.

26. Turbanov I.S., Ivanitsky A.N. 2018. Horseshoe Bats (Chiroptera, Rhinolophidae) in the southwestern Crimea and problems of their protection. Russian Journal of Theriology, 17 (1): 39-47.

27. Uhrin M., Gazaryan S., Benda P. 2009. Does Tadarida teniotis really occur in Crimea? (Chiroptera: Molossidae). Lynx, n. s. (Praha), 40: 115-126.

28. Zagorodniuk I.V. 1999. Taxonomy, biogeography and abundance of the horseshoe bats in the Eastern Europe. Acta Zoologica Cracoviensia, 42 (3): 407-421.

\section{References}

1. Beskaravayny M.M. 1985. O novoy nakhodke sredizemnomorskogo netopyrya v Krymu [The new record of Kuhl's pipistrelle bat in the Crimea]. Vestnik zoologii, 4: 82-83.

2. Beskaravayny M.M. 1988. Sovremennoye sostoyaniye fauny rukokrylykh Karadaga (Krym) [The current state of the bat fauna of the Karadag (Crimea)]. In: Rukokrylye (morfologia, ekologia, ekholokatsia, parazity, okhrana) [Bats (morphology, ecology, echolocation, parasites, protection)]. Collection of scientifical works. Kiev, Naukova dumka: 113-116.

3. Beskaravayny M.M., Shevchenko L.S. 1989. Mlekopitayuschie [Mammals]. In: Priroda Karadaga [Nature of the Karadag]. Kiev, Naukova dumka: 221-228.

4. Beskaravayny M.M. 1990. Mlekopitayushchiye [Mammals]. In: Karadagskiy gosudarstvennyy zapovednik AN USSR. Letopis' prirody. 1987. Tom IV. Kniga 2 [Karadag State Reserve of the Academy of Sciences of the Ukrainian SSR. Chronicle of nature. 1987. Vol. IV. B. 2.]. Simferopol, Red Department of the Crimean Regional Polygraph Publishing House: 74-75.

5. Brauner A.A. 1911. Letuchie myshi Kryma [Bats of the Crimea]. Zapiski Kremskogo obschestva estestvoispytateley $i$ lyubiteley prirody, 1: 1-13.

6. Vronsky A.A., Krivobokov E.M., Kostenko N.S., Baranov I.A., Beskaravayny M.M., Budashkin Yu.I., Vladimirov E.I., Klyukin A.A., Pyanikh S.V., Semenkov P.G., Shatko V.G., Schepinsky A.A. 1997. Kurort Koktebel [The Koktebel resort]. Kiev, Naukova dumka, 134 p.

7. Godlevskaya E.V., Ghazali M.A., Tischenko V.N. 2013. First record of Myotis dasycneme (Chiroptera) in the Crimea. Vestnik zoologii, 47 (1): 38. (in Russian)

8. Dulitsky A.I., Kovalenko I.S. 2003. Materialy po rukokrylym Kryma v zoologicheskikh sobraniyakh Ukrainy i Rossii [Data on the Crimea bats in zoological collections of Ukraine and Russia]. In: Voprosy razvitiya Kryma: Problemy inventarizatsii krymskoy bioty [Issues of the development of the Crimea: Problems of inventory of the Crimean biota]. Vol. 15. Simferopol, "Tavria Plus": 197-210.

9. Dulitsky A., Mikhaylova O. 2001. Do kharakteru perebuvannya kazhaniv na terrytoriyi Krymu [On the character of bat species presence in the Crimea]. In: Migratsiyny status kazhaniv Ukrayini [Migration status of bats in Ukraine]. Kyiv, UTT: 106-109. (in Ukrainian) 
10. Ivanitsky A.N. 2018. Rukokrylye (Chroptera) Abkhazii I sopredelnykh territiriy (fauna, ekologia, zoogeografia, okhrana) [Bats (Chroptera) of Abkhazia and adjacent territories (fauna, ecology, zoogeography, protection)]. Simferopol, PT “ARIAL”, 156 p.

11. Ivanitsky A.N., Vasenkov D.A., Sidorchuk N.V. 2019a. New faunistic records of bats in the Eastern Crimea. Plecotus et al., 22: 69-79. (in Russian)

12. Ivanitsky A.N., Rosenberg O.G., Shorenko K.I. 20196. Aq-Monay limestone mines important refuge for bats in the Eastern Crimea. Ecosystemy, 20 (50) (in Russian)

13. Ivanitsky A.N., Sidorchuk N.V., Vasenkov D.A. 2018. New data on bats of eastern part of the Southern coast of Crimea. Ecosystemy, 16 (46): 117-122. (in Russian)

14. Kojurina Je.I., Borisenko A.V., Panjutina A.A., Morozov P.N. 2002. K izucheniyu rukokrylykh Abrau [To the researches of the bat fauna on Abrau Peninsula]. In: Bioraznoobrazie poluostrova Abrau [Biodiversity of the Abrau Peninsula.]. Moscow, Moscow State University: 106-112.

15. Kukushkin O.V. 2004. Otryad Rukokrylyye (Chiroptera) [Order Bats (Chiroptera)]. In: Karadagsky gosudarstvenny zapovednik Natsionalnoy Akademii nauk Ukrainy. Letopisi prirody. T. XX. 2003 god [Karadag State Nature Reserve of the National Academy of Sciences of Ukraine. Annals of Nature. Vol. 20. 2004]. Simferopol, SONAT: 239-240.

16. Kukushkin O.V. 2010. Nablyudeniya nad redkimi vidami rukokrylykh Karadaga [Observations of rare species of bats of the Karadag]. In: Karadagsky gosudarstvenny zapovednik Natsionalnoy Akademii nauk Ukrainy. Letopisi prirody. T. XXV. 2008 god [Karadag State Nature Reserve of the National Academy of Sciences of Ukraine. Annals of Nature. Vol. 25. 2008]. Simferopol, N. Orianda: $277-280$.

17. Kukushkin O.V., Pokinchereda V.F. 2008. Rezul'taty uchetov rukokrylykh v Karadagskom prirodnom zapovednike [Results of counts of bats in the Karadag nature reserve]. In: Karadagsky gosudarstvenny zapovednik Natsionalnoy Akademii nauk Ukrainy. Letopisi prirody. T. XXIII. 2006 god [Karadag State Nature Reserve of the National Academy of Sciences of Ukraine. Annals of Nature. Vol. 23. 2006]. Simferopol, N. Orianda: 305-309.

18. Kukushkin O.V., Pokinchereda V.F. 2014. Rukokrylyye. Nablyudeniya v Karadagskom zapovednike v 2013 g. [Bats. Observations in the Karadag Nature Reserve in 2013]. In: Karadagsky gosudarstvenny zapovednik Natsionalnoy Akademii nauk Ukrainy. Letopisi prirody. T. XXX. 2013 god [Karadag State Nature Reserve of the National Academy of Sciences of Ukraine. Annals of Nature. Vol. 30. 2013]. Карадаг: 140-141.

19. Kukushkin O.V., Pokinchereda V.F., Beskaravayny M.M., Krasnikov A.E. 2007. Nablyudeniya nad sovmestnoy materinskoy koloniyey dvukh redkikh vidov rukokrylykh (Chiroptera) v Karadagskom zapovednike v 2005 godu [Mammals. Observations of the joint maternal colony of two rare species of bats (Chiroptera) in the Karadag Nature Reserve in 2005]. In: Karadagsky gosudarstvenny zapovednik Natsionalnoy Akademii nauk Ukrainy. Letopisi prirody. T. XXII. 2005 god [Karadag State Nature Reserve of the National Academy of Sciences of Ukraine. Annals of Nature. Vol. 22. 2005]. Simferopol, SONAT: 292-297.

20. Lopatiuk A.L. 2008. Nakhodki malogo podkovonosa (Rhinolophus hipposideros Bechstein, 1800) v Karadagskom zapovednike [Records of the Lesser Horseshoe bat (Rhinolophus hipposideros Bechstein, 1800) in the Karadag Nature Reserve]. In: Karadagsky gosudarstvenny zapovednik Natsionalnoy Akademii nauk Ukrainy. Letopisi prirody. T. XXIII. 2006 god [Karadag State Nature Reserve of the National Academy of Sciences of Ukraine. Annals of Nature. Vol. 23. 2006]. Simferopol, N. Orianda: $303-305$.

21. Ognev S.I. 1928. Zveri Vostochnoy Evropy i Severnoy Azii. T.1. Nasekomoyadnye i letuchie myshi [Beasts of Eastern Europe and Northern Asia. V. 1: Insectivores and Bats]. Moscow-Leningrad, Gosizdat, $631 \mathrm{p}$.

22. Sludsky E.A. 2004-2005. Karadag. Vosspominania (1917-1926 gg.) [The Karadag Memories (1917-1926)]. Simferopol, SONAT, 112 p.

23. Smirnov D.G., Kurmaeva N.M., Ivanitsky A.N. To the study of bats (Chiroptera) of the Eastern Crimea. Plecotus et al., 20: 17-29. (in Russian)

24. Bat census in Crimean caves. 2007. A final report on the BP Conservation project. L. Godlevska (project leader). Kyiv, $41 \mathrm{p}$.

25. Benda P., Gazaryan S., Vallo P. 2016. On the distribution and taxonomy of bats of the Myotis mystacinus mophogroup from the Caucasus region (Chiroptera: Vespertilinidae). Turkish Journal of Zoology, 40: 1-8. 
26. Turbanov I.S., Ivanitsky A.N. 2018. Horseshoe Bats (Chiroptera, Rhinolophidae) in the southwestern Crimea and problems of their protection. Russian Journal of Theriology, 17 (1): 39-47.

27. Uhrin M., Gazaryan S., Benda P. 2009. Does Tadarida teniotis really occur in Crimea? (Chiroptera: Molossidae). Lynx, n. s. (Praha), 40: 115-126.

28. Zagorodniuk I.V. 1999. Taxonomy, biogeography and abundance of the horseshoe bats in the Eastern Europe. Acta Zoologica Cracoviensia, 42 (3): 407-421.

Поступила в редакиию 13.10.2020

\section{Ссылка для цитирования статьи \\ For citation}

Иваницкий А.Н. 2020. К фауне рукокрылых городского округа Феодосия. Полевой журнал биолога, 2 (4): 298-309. DOI 10.18413/2658-3453-2020-2-4-298-309

Ivanitsky A.N. 2020. On the bat fauna of the urban district of Feodosiya. Field Biologist Journal, 2 (4): 298-309. DOI 10.18413/2658-3453-2020-2-4-298-309 (in Russian) 